\title{
Woman Subculture Development Seen from Woman Language
}

\author{
Liwei Zhu \\ Tianjin Polytechnic University, Tianjin, China \\ Email: puppylele@126.com
}

\begin{abstract}
The woman subculture study is widely conducted through several decades since the beginning of the second wave feminist movement in 1960s. This paper intends to explain the woman subculture development in view of the woman language. First, it gives the definition of subculture. Second, it explains why woman culture is considered as a subculture. Third, with reference to sociolinguistic studies of woman language, it offers further clarification of some important feminist theories like gendered knowledge, standpoint theory and muted group theory. Also some key conceptions which are closely tied to woman subculture are expounded through the analysis of woman language. Last, the paper explains how woman subculture is transmitted through feminist theories and literary criticism works and how it is divided into three phases.
\end{abstract}

Index Terms - woman subculture, woman stereotype, gender role, woman language

\section{Definition of SubCUlture}

Subculture is defined as a subdivision within the dominant culture that has its own norms, values and belief system. Riesman (1950) defines it as a culture or set of people with distinct behaviour and belief within a larger culture.

Subcultures emerge when individuals in similar circumstances find themselves virtually isolated or neglected by mainstream society. Thus they group together for mutual support. It exists within the larger society, but apart from it. The members of the subculture are different from the dominant culture. A culture often contains numerous subcultures which incorporates large parts of their mother culture, but in specifics, they may differ radically. Some subcultures achieve such a status that they acquire a name of their own.

\section{WOMAN SUBCULTURE}

Women, as a marginalized group in society, are displaced by the mainstream culture. This can easily be perceived through every part of our life ranging from politics, economy, and culture to family life. Linguistically speaking, there are numerous derogative terms describing women. Culturally, stories about women's degeneration are prevalent both in the east and west. Even great philosophers and thinkers hold negative opinions on them. Their voices are silenced by various taboos imposed on them and they have to employ "back channel" to communicate with each other, which is reckoned as euphemism. Woman subculture comparatively differs from other subcultures (punk subculture, hippie subculture, youth subculture) in the notion that it is closely interconnected with gender.

\section{A. Theories Related to Woman Subculture}

There's a perception in recent years that woman subculture is closely tied to some important feminist theories like gendered knowledge and muted group theory. Without the further clarification of these theories, it would be impossible to analyse woman subculture.

These theories which are of great relevance to woman subculture are found in an article in Time Magazine, The Real Truth About the Female Body.

First one is theory of gendered knowledge. It maintains that men and women have access to different phenomenological knowledge, that is, knowledge, know-how and personal knowledge of others, by virtue of their gender and they also tend to represent the world in different terms, by virtual of their gendered interests, attitudes, emotions and values and perhaps also by virtue of different cognitive styles. The differences are also informed by the constructions, institutions and exercises of power in society. It's possible to mystify the study of gendered knowledge by treating gender as the only category of discrimination and difference---by ignoring the way class, race and other socially-produced categories impact on access to knowledge, goods and power, on self-perception, on the formation and possibilities of the self as internally realized and as socially empowered or disempowered.

The second one is muted group theory. It grows out of ethnology, the study of cultures, and the observation that marginalized groups (a) do not to have a voice in the culture---not only do they not have a say explicitly, but in fact are silenced, do not have the right to speak and (b) these groups tend to develop alternative ways of communicating, what is sometimes called "back-channel" communication, as the slaves in North American developed an elaborate communication code through which they were able to communicate right in front of the master's eyes without being 
aware of what meanings were being made.

The general claim of muted group theory is amply supported in studies in socio-linguistics. In the mid 70s, Robin Lakeoff theorized that there was such a thing as "women's speech" in that women tended to interrupt less, to speak with less certainty using hedges (I myself think that) and tags (don't you think), and to speak less and with less authority. Subsequent research has proved that this speech style exists. Not only women speak it, but also men from marginalized situations-- the poor, the powerless.

In the realm of gender, as well, the territory of human life has been divided into "the external world" and "the domestic world", which women having speech rights in one but not in the other. Women tend to speak or have spoken with reference to one realm of this divided experience, men another.

So Muted Group Theory predicts that the marginalized will not have the rights of public speaking and will be silenced in the public realm, but that they will develop back-channel, in-group speech which will be decoded by their own members but not by the dominant group--unless they listen very carefully, knowing what they're listening for.

\section{B. Some Key Conceptions Relating to Woman Subculture}

\section{Woman Stereotype}

Woman stereotype is a key conception in understanding woman subculture; it also provides a guide to the deep analysis of woman studies. Woman stereotype is the traditional and universally accepted image that has been long and deeply rooted in people's mind.

Woman stereotype is closely interwoven into the social conventions and social norms that have been formalized since the primary societies. The ideology of the mainstream society, women's involvement in the public and private realm as well as the media-presentation--all these external factors contributed to the formation and consolidification of women imagine and women stereotype.

Besides these external factors, some internal factors such as woman psychology have to be taken into account. Men and women grow up in different cultures. From childhood, girls are told by their parents to behave like ladies. There're many rules and restrictions imposed upon them such as the way they speak, dress and so on. The little girl from early age has become conscious of what a good girl should be like although she doesn't know the conception of "woman stereotype". In people's eyes, woman should be attractive, docile and compliant. More importantly, women should be very polite, because they are the preservers of morality and civility. They should stay at home and take on the supportive and caring role as wives and mothers.

In a research done by Bennet \& Sandra. K on stereotyped images of women, a list of the images of women is taken from examples of high school literature. It is discovered that the woman's role is defined strictly within the home and childbearing and the high school literature usually portray women as passive and subordinate. The male gender role stereotype, on the other hand, is very active and aggressive.

This woman stereotype also can be easily seen in English language. The most vital and influential professions, when they are used for woman, will plus the word "woman", for example, woman doctor, woman professor, woman president. It's common to say Mary is John's widow. However, John is Mary's widower is hardly used. In the first sentence, there is an implication that though John is dead, Mary is still defined by her relationship to him. The inappropriateness of second sentence is that when Mary is gone, her function for her husband John is over.

Once again, it can be seen that women are always defined in term of men and given their identities in our society by virtue of their relationship with men, not vice versa. Consequently, both the way women are spoken about and the way women speak can be traced back into the woman stereotype that is deeply set in the society. By drawing comparisons between men and women's ethical sense, Carol Gilliglan (1993) in her book A Different Voice gives a clear conception of woman stereotype. In this book, Carol draws a clearline between man and woman's certain behaviours. However, both extreme positions are rarely found in reality. Actual behaviour of individuals is somewhere between these poles. The most common "model" followed in real life is the "model of double burden".(p,42) According to the interactionist approach, roles (including gender) are not fixed, but are constantly negotiated between individuals. Gender role can influence all kinds of behaviour, such as choice of work, personal relationship and of course the way men and women speak.

Also Tannen (1994) suggests that the two sexes have very different modes of communication, and she suggests that in fact communication between man and woman ought to be viewed as inter-cultural communication. She also has given set of differentiations: (1) Men live in a world of hierarchy; women live in a world of connection. (2) Men require independence; women require intimacy. (3) Men live in a world of action; women live in a world of feeling.(p,67)

The issue Tannen tries to address is that sometimes women and men don't understand each other because they come from different cultures. These findings on gender stereotypes offer a great help to them for understanding each other and thus enhance their relationship.

Women are not only biologically constructed but socially constructed as well. Hence, evaluating not only the persuasive power of the stereotype but also its use as an analytical tool is one of the recognized insights of feminist linguistic research.

Gender Role

Another key conception that helps to better perceive woman subculture is gender role. It's generally believed that gender and sex are the same thing. However, they're essentially not the same. Gender is defined from social viewpoint, 
while sex is defined biologically. When we mention woman subculture, it would be essential to have some ideas about gender role under whose framework women function in a society.

In the social sciences and humanities, a gender role is a set of behavioural norms associated with a given gendered status (also called gendered identity) in a given social group or system. J.B Pride (1986)says Gender is one component of the gender/sex system, which refers to "the set of arrangement by which a society transforms biological sexuality into products of human activity and in which these transformed needs are satisfied" (p,248) Every known society has a gender/sex system, although the components and working of this system vary widely from society to society.

In many ways, gender identity and roles function as any other social identity and role. Every known human society presents individuals with a set of statuses by which members of the society identity themselves and one another. Such statuses may be assigned to an individual automatically, based on the status of his or her parents; or based on some physical characters that are called "ascribed". Other statuses may be "achieved", based on the activities and accomplishments of an individual.

Some scientists used to believe that gender was universally ascribed, today most people recognize that elements of gender can be achieved. In either case, gender, like any other role, involves socially proscribed and prescribed behaviours, which may take the form of rules or values. However, such rules and values don't determine or control an individual's behaviours absolutely. In most cases, they define boundaries of acceptable behaviour within which there is always variation and room for individual creativity. Most researchers recognize that the concrete behaviour of individuals is a consequence of socially defined rules and values, and individual disposition, whether they are genetic, unconscious or conscious. Although some researchers emphasize the objective social system, and others emphasize subjective orientations and dispositions.

It has long been recognized that cultures and societies are dynamic and changeable, there have been extensive debates as to how, and how fast, they may change. Such debates are especially intense when they involve the gender/sex system, as people have widely different views about the extent to which gender depends on biological sex.

Working in the United States, Talcott Parsons developed a model of the nuclear family in 1955. It compared a strictly traditional view of gender roles to a more liberal view. Parsons [58] believed that the feminine role was an expressive one, whereas the masculine role, in his view, was instrumental. He believed that expressive activities of the woman fulfill "internal" functions, for example to strengthen the ties between members of the family. The man, on the other hand, performed the "external" functions of a family, such as providing monetary support. The Parsons model was used to contrast and illustrate extreme positions on gender roles.

\section{WOMAN SUBCULTURE DEVELOPMENT}

\section{A. The Transmission of Woman Subculture}

As illustrated in the previous part, woman subculture is created in part by male dominance and the exclusion of women from certain realms: they had been oppressed, reflected and devalued for centuries. Their voices couldn't be recognized and accepted by mainstream society. Consequently, they group together to offer mutual help. However, woman subculture is unique in its own way in that its development helps the development of the whole female social construction: their psychological, societal economic and political demands have been voiced. Woman subculture is incorporated into all aspects of women life: economy, politics, literature, history, living style and so on. Today, for the increasing awareness of women's existence and women's power, both official and unofficial means ranging from policy institution, social activities to medial representation are adopted to promote a positive and healthy woman image and this helps to develop woman culture. The mass media, newspapers, magazines and TV have played a dominant role in assisting the formation and rapid development of woman subculture.

It has been noted long time ago that women have been participating actively and enthusiastically in the media realm. They work as journalists, editors, anchorpersons, guest speakers, interviewers and so on. They try to unfold and recount their experiences as wives and successful career women. These experiences include what their emotional life is like; how they balance their role in the private and public arena; what difficulties they have encountered during the process of pursuing their goals; how they look at some controversial issues in the society. The ways they tell as well as the expressions they employ suggest, to a certain extent, women's independence from men in terms of text and textuality. This could be an obvious indicator of women's effort to try to establish their own discourse, which in the past, never existed in the male-dominated world. Till now this effort has received more widespread attention.

In the second wave and third wave feminist linguistics, the establishment and development of women's discourse right had already been to put to agenda. In support of this big plan, feminists, sociologists as well as social linguists corporate to reform some feminist and linguistic theories in order to explicitly interpreted female culture.

Although there is the idea in 1990s in academic circle that the concept of women's culture is no longer used, in the early 1980s, the concept of women's culture flared briefly in scholarly studies of women. Ironically, shortly after academics abandoned the concept of women's culture, there came the best sellers "Men are from Mars, women are from Venus" by John Gray. He proposes that men and women are so different from one another that they virtually come from different planets. It also became popular in everyday conversation for the idea of culture to be used all the time, and it ultimately became popular discourse to use words such as black culture and culture shock. Later, Lebsock (1992) herself had to admit that some notion of women's culture could again be useful to historians, especially if we think in 
terms of women's cultures. So the important differences among women could be taken into account as well as what they may have in common.

One of the reasons the concept of women's culture was caught onto women scholars in the 1980s was the hope that empowering women would be transformational, that as women gained power, they would bring more humane values into power structure of the world. The need for the transformation--working towards human values--is just important as ever." (p,105)

In the literature field, women writers like Virginia Woolf (1929) calls for the culture revolution among women. In her work "A Room of One's Own" she writes: "We won't be able to define the difference until women will express themselves in every field of the human activity as fulfilled subjects." (p,103) In other words, woman literature provides good tools for the study of woman subculture. Through literature language, female writers sublimate woman's life and experiences into an art. Looking back at literature history, though many male writers created successful women imagines: Portia in Merchant of Venice; Cleopatria in Anthony and Cleopatria; Tess in Tess of Derberville, yet, no male writers would describe female psychology and experiences as well as female themselves do. One of reasons might be that men always look at women from men's viewpoint. They tend to trust their intuitions about women which in most cases prove wrong. When Pope thinks that Clarissa's genteel response to the outrage against Belinda is more acceptable than Belinda's quite understandable outrage, both at the act of violence against her and at her powerlessness, women want to point out that the model of woman that pope is constructed is one that is ideally suited to serve male ends.

Showalter (1992) also gives a brief example of the work written by Hardy "The Mayor of Casterbridge". She argues that this piece of work is male-oriented, devoted to exposing what men thought women were and should be; it tends to naturalize women's oppression by focusing on it. A great deal of very interesting work has been done in this tradition. G.M. Hopkins (1985) says that women can't write creatively because they lack the male generative powers. Contrary to such prejudice, female writers demonstrated their versatile writing skill and their great capability to manipulate words. More importantly, being women themselves, they know women best. No male writers could ever present the heroine in "To the Lighthouse" in the same way as Virginia Woolf does; no male writers can highlight mother love in such a way as Tony Morrison in her Pulitzer-winning work---“Beloved". The heroine growing out of male writer's work are mostly flat and unifaced; while these characters turn out to be three-dimensional and multifaceted in the hands of female writers. The complexity of female psychology is vividly displayed by their fluid language.

Thus, in some women's literature, feminine values penetrate and undermine the masculine systems that contain them. "... and women have imaginatively engaged the myths of the Amazons and fantasies of a separate female society, in genres from Victorian poetry to contemporary science fiction." (Showalter, 1992,130) She goes on to say that attention to women writers of the past means attention to the sociological structures that they inherited, the economic, moral and psychological pressures they faces, and the strategies for survival and for self-expression: only then can women's literature of the past be read clearly.

For the purpose of better understanding woman culture, the theory-gynocrtics is put forward. Gynocritics focuses on women's texts, textuality, creativity and traditions. It's the development of new models based on women's experiences. Showalter (1992) writes: "It begins at the point where we free ourselves from the linear absolutes of male history, stop trying to fit women between the lines of the male tradition, and focus instead on the newly visible world of female culture." (p,152) Gynocrotics is related to feminist research in history, anthropology, psychology and sociology, all of which have developed hypotheses of a female subculture including the occupations, interactions and consciousness of women. Anthropologists study the female subculture in the relationship between women as mothers, daughters, sisters and friends; in sexuality, reproduction, and ideas about the body.

\section{B. Three Phases of Woman Subculture Development}

According to Showalter (1992), woman culture is basically divided into three phases: the feminine, the feminist and the female. $(\mathrm{p}, 119)$

First, the feminine: during this phase, women wrote out of their subcultures and attempt to make equal achievements of male culture. They also want to develop and enlarge the domain of female representations. These women included women's perspective and concerns obliquely and subvertly. This phase dates till 1880 or so.

Second, the feminist: the phase of conscious rebellion, the feminist phase, 1880-1920: this was the time of the requirement for the vote for woman, a time of great feminist action. There were many political and sociological movements during this period.

The third phase is the female: the establishment of woman's role and nature as genuine, creative, independent and different.

Going through all the three phases, woman subculture development now poses the most exciting challenge for the new millennium: expanding and advertising women's thought and reflection starting from the many subjects where they are already present, from physics to philosophy, from psychoanalysis to sociology, from economics to law, from ethics to sexology. Therefore, the transmission and spreading of woman subculture become very important.

\section{ACKNOWLEDGEMENT}

I'd like to express my great appreciation to Zhang Wei, who has spared his valuable time to read through this paper in 
draft form and made many helpful suggestions and comments. I must also deliver my sincere gratefulness to my very beloved teacher Brian Barrons, who has provided me with many materials needed to complete this paper. Without his great help and support, I would not have been able to finish it.

\section{REFERENCES}

[1] Aries, Elizabeth. (1996). Men and women in interaction. Oxford University Press.

[2] Brown, Penelope. (1980).How and why are women more polite: Some evidence from a Mayan community. In Sally McConnell-Ginet, Ruth Borker, \& Nelly Furman (eds.) Woman and language in literature and society. New York: Praeger.

[3] Butler, Judith. (1990).Gender trouble. New York: Routlege.

[4] Cameron, Deborah. (1994). Problem of sexist and non-sexist language. In Jane Sunderland (eds.), Exploring gender: Question for English language education. London: Prentice-Hall.

[5] Cameron, Deborah (ed.) (1990).The feminist critique of language. 2nd ed. London: Routledge.

[6] Carol Gilliglan. (1993).In a Different Voice: Psychological Theory and Women's Development. Harvard University Press. Reissue edition.

[7] Crawford, Mary. (1995).Talking difference: On gender and language. London: Sage.

[8] Echols, Alice. (1985).Daring to be bad: Radical feminism in America, 1967-1975. University of Minnesota Press.

[9] G.M. Hopkins (2001). An inventory of the Anthony Bischoff Research Collection at Gonzaga University English Literary Studies, University of Victoria.

[10] Holmes, Janet. (2000). Ladies and gentlemen: Corpus analysis and linguistic sexism. In Chritian Mair \& Marianne Hundt (edt.), Corpus linguistics and linguistic theory: Papers from the 20th International Conference on English Language Research on Computerized Corpor.

[11] Holmes Janet \& Miriam Meyerhoff. (2003).The handbook of language and gender. Oxford: Blackwell.

[12] Holmes, Janet. (1995).Women, men and politeness. London: Longman.

[13] James, Deborah, \&Sandra Clark. (1993).Women, men and interruptions: A critical review. Oxford University Press.

[14] Kira Hall \& Mary Bucholtz. (1995).Gender articulated: Language and the socially constructed self. New York: Routledge.

[15] Lakeoff. R. (2004).Language and Woman's Place: Text and Commentaries. Oxford University Press.

[16] Nancy A. Hewitt, Suzanne Lebsock. (1992). Visible women: new essays on American activism. University of illinois press.

[17] Ochs, Elinor. (1992). Indexing gender. In Barbara Diane Miller (eds.), Sex and gender hierarchies. Cambridge University Press.

[18] Parsons. (1991). The social system. Routledge.

[19] Pride, J.B. ( 1986).The Social meaning of language. London: Oxford University Press.

[20] Riesman. (1950). The lonely crowd: a study of the changing American character, Yale University Press.

[21] Showalter, Elaine. (1992).The Female Malady: Women, Madness, and English Culture .Oxford University Press.

[22] Tannen Deborah. (1994).The relativity of linguistic strategies: Thinking power and solidarity in gender and dominance. In Deborah Tannen (eds.), Gender and discourse. Cambrige University Press.

[23] Tannen, Deborah. (1994). You just don't understand: Women and men in conversation. New York: William Morrow.

[24] Time Magazine, (1999). The Real Truth About the Female Body, March 8.

[25] Virginia Woolf. (1929).A Room of One's Own. Harcourt Brace and Company.

Liwei Zhu was born in Jilin China in 1981. She received her M.A. in linguistics from BeiHua University, China in 2006.

She is currently a Lecturer in the School of Foreign Languages, Tianjin Polytechnic University, Tianjin, China. Her research interests include second language acquisition and sociolinguistics. 